\title{
Edição genética associada ao uso da nova técnica CRISPR/Cas9, ferramenta de defesa utilizada pelas bactérias contra DNA invasor
}

\begin{tabular}{lc}
\hline $\begin{array}{l}\text { Amanda Aparecida Lins } \\
\text { Flavio Buratii Gonçalves }\end{array}$ & $\begin{array}{l}\text { Universidade de Guarulhos (UnG). } \\
\text { E-mails: a manda lins@hotmail.com }\end{array}$ \\
\hline Priscila Luiza Mello & $\begin{array}{l}\text { Doutora em Biologia Geral e Aplicada. } \\
\text { Universidade Estadual Paulista (UNESP) } \\
\text { E-mail: priscila mello@msn.com }\end{array}$ \\
\hline
\end{tabular}

Recebido em: 13 outubro 2017. Aceito em: 20 janeiro 2018.

DOI: http://dx.doi.org/10.21674/2448-0479.43.358-367

\section{Resumo}

O tema edição genética é algo que ainda traz muitas dúvidas as pessoas, afinal, o material genético é tudo aquilo que forma uma pessoa, tudo aquilo que se herdou e que irá passar de geração em geração. Este trabalho traz uma revisão sobre ferramentas da edição. A técnica CRISPR/Cas9 é uma das ferramentas que faz o impossível parecer possível. É um mecanismo análogo ao sistema imunológico encontrado em diversas bactérias para se defenderem de um DNA estranho, como o de vírus, por exemplo. Os estudos iniciais foram feitos, em especial, com bactérias de espécie gram-positivas, com morfologia de coco, denominadas Streptococcus pyogenes. Diante da revisão exposta, com a descoberta dos métodos e o funcionamento da técnica CRISPR/Cas9, acredita-se que serão possíveis grandes avanços científicos, até mesmo para o tratamento de doenças que atualmente não se tem cura.

Palavras-chave: Material genético. Defesa. Streptococcus.

\section{Abstract \\ Genetic editing associated with the use of new CRISPR/Cas9 technique, a defense tool used by bacteria against invasive DNA}

The issue of genetic editing is something that still brings many doubts to people, after all, genetics is everything that forms a person, everything that has been inherited and that will pass from generation to generation. It's a review about editing tools. The CRISPR/Cas9 technique is one of the tools that makes the impossible seem possible. It is a analogous mechanism of the immune system found in several bacteria to defend themselves against a foreign DNA, such as viruses, for example. The initial studies 
were done in particular with gram positive bacteria with coccus morphology, called Streptococcus pyogenes. In the light of the review, with the discovery of the methods and the operation of the CRISPR/Cas9 technique, it is believed that great scientific advances will be possible, even the treatment for diseases that currently do not cure.

Keywords: Genetic material. Defense. Streptococcus.

\section{Introdução}

A edição genética é um assunto que causa muitas discussões no mundo atual, onde se pode ouvir que é possível modificar uma parte específica do Ácido Desoxirribonucleico (DNA) ou até mesmo uma sequência, com a edição é possível remover aquilo que é indesejado ou até mesmo acrescentar e modificar aquilo que é desejado. Muitas discussões entram em questão, pois seria mesmo possível modificar algo que para muitos seria impossível?

Sim, é possível, e o estudo da edição genética traz cada vez mais novas técnicas que podem nos ajudar muito, pois é uma ferramenta importante para estudos funcionais de genes, bem como a melhoria de uma determinada situação (GAO et al., 2017). A edição genética tem um proveitoso uso de novas tecnologias que podem ser introduzidas na quebra de uma determinada região da dupla fita de DNA, sendo que essa quebra do DNA é bastante útil, pois ativa o sistema de reparo de DNA natural da célula, que pode ser explorado para melhorar significativamente a eficiência de introduzir alterações da qual o indivíduo seja favorecido com a mutação realizada no genoma, e não uma mutação indesejável levando a complicações. (MUSURUNU, 2017).

Com todo o avanço tecnológico, as pesquisas e experimentos realizados foram possíveis o descobrimento de uma nova técnica, denominada CRISPR/Cas9 (Clustered Regularly Interspaced Short Palindromic Repeats). O sistema formado por repetições palindrômicas curtas, interespaçadas e regularmente agrupadas (AREND et al., 2016), é uma ferramenta poderosa para modificação genética, onde é capaz de reconhecer uma região e realizar a edição (MEN et al., 2017). Com base no grande progresso da compreensão da técnica, a tecnologia CRISPR/Cas9 foi ampliada em cenários crescentes para investigação. Como a tecnologia de sequenciação avançada identificou uma vasta base genética causadora de doenças humanas, os kits de ferramentas CRISPR agora podem mediar uma correção genética ou até mesmo uma interrupção (LIN et al., 2017).

Assim, é possível imaginar que com o grande avanço da tecnologia há esperança de que existirá uma possível cura para doenças que atualmente não tem uma grande taxa de sucesso, ou até mesmo o fim de determinada doença que pode ser passada de gerações em gerações entre familiares. Portanto, este trabalho tem como objetivo fazer uma revisão bibliográfica para compreender o funcionamento dessa nova técnica, bem como possibilitar o acesso à informação, para que todos que possuem interesse possam adquirir mais conhecimento sobre esse tema, que é um grande avanço na área da saúde e na Genética Humana. 


\section{Material e Métodos}

Trata- se de um estudo de revisão, onde as buscas foram realizadas em duas bases de dados bibliográficos Scientific Eletronic Library OnLine - Scielo e Public Medline - Pubmed. Foram selecionados artigos em português e inglês, sendo que os mais utilizados foram os artigos em inglês. O levantamento de dados foi realizado durante o ano de 2017, priorizando informações dos últimos cinco anos, a partir das palavras chaves "Crispr", "Crispr/Cas9", "Gene editing" e "Crispr/Cas9 system".

\section{Revisão bibliográfica}

\section{Edição genética}

A edição genética é uma família de tecnologias que permite que o DNA direcionado sofra alterações em sua sequência dentro dos genomas de células eucarióticas. O uso da edição transformou muitos domínios da pesquisa biológica e é uma grande promessa para a medicina e a agricultura no futuro próximo (DEWITT et al., 2017).

O termo "edição" implica em um processo preciso e previsível pelo qual o genoma pode ser alterado, e nos últimos anos as pesquisas para o desenvolvimento de uma melhor ferramenta que possa realizar a edição genética foi então iniciado (NICHOLSON, 2016); sendo uma das ferramentas usada atualmente, pela engenharia genética em que o DNA pode ser removido, substituído ou inserido de um genoma em uma determinada região (ZHENG et al., 2017). É um assunto que desde o início dos estudos gerou grande discussão por modificar algo que teoricamente seria impossível a alteração. Gerar uma nova espécie a partir de uma modificação no próprio genoma ainda é um grande obstáculo para muitos pesquisadores (HUIJBERS, 2017), pela questão ética, onde deve passar por uma série de aprovações e experimentos in vitro para que somente assim possa ser realizada in vivo.

E assim, a identificação de uma ferramenta para mudar o genoma começou lentamente, mas durante os últimos anos cresceu e, finalmente parece haver uma tecnologia com potencial genuíno para revolucionar o campo da engenharia do genoma (NICHOLSON; PEPPER, 2016). Ao longo da última década, as pesquisas vêm avançando, e com isso novas descobertas de diferentes técnicas para realizar a edição e com os avanços, o sistema CRISPR/Cas9 é considerado o mais notável na tecnologia de edição do genoma (ZHENG et al., 2017), que veio à atenção geral ainda no início de 2013 e desde então criou grande atenção na comunidade biomédica, por causa de sua facilidade de uso e sua eficácia comparada com as outras ferramentas (MUSUNURU, 2017).

\section{Novo sistema}

No final da década de 80 , quando o pesquisador Ishino e colaboradores analisaram uma determinada sequência do gene iap da bactéria Escherichia coli, foi possível encontrar uma estrutura incomum, diferente do que se é costumado a observar. Posteriormente, repetições similares foram 
identificados pelo sequenciamento aleatório de todo o genoma em numerosas outras bactérias. Essas sequências de repetição agrupadas, que são regularmente espaçadas por sequencias interativas únicas de comprimento constante, denominadas "Short Regular Spaced Repeats (SRSRs)", foram eventualmente classificadas como uma família genética única, presente no sistema imunitário procariótico, que proporciona resistência adquirida contra vírus. A unidade repetida e as repetições invertidas curtas são características semelhantes aos sítios reconhecidos para certas proteínas de ligação ao DNA. No entanto, essas descobertas levantaram um grande questionamento se a sua presença é uma reminiscência das antigas sequências ou um sinal de que estaria evoluindo. Em meados do século 20, pesquisadores designaram isso sendo uma nova família repetitiva "CRISPR" (WU et al., 2017). O qual foi descoberto sendo um mecanismo imune adaptativo bacteriano, que pode ser alvo de sequências específicas de ácidos nucleicos estranhos. O CRISPR consiste em sequências espaçadoras únicas delineadas por sequências curtas, repetitivas, palindrômicas e codificação de sequências de Proteínas Cas (KOLLI et al., 2017), que através de estudos e análises, foi possível então que pudessem descobrir vários genes localizados adjacentes ao cluster de repetição e posteriormente os referiu como genes associados à CRISPR, ou Cas genes. Esses sistemas foram sugeridos para desempenhar papéis no DNA como reparação e regulação, e na proteção contra agentes estranhos, como vírus em procariotas.

Com o passar dos anos, o interesse foi ficando cada vez maior, e o que se pode descobrir é que o sistema CRISPR/Cas é na verdade categorizado em três grandes tipos (I, II e III), sendo que do tipo II é o mais utilizado e é composto por proteínas multifuncionais como a própria Cas9. O produto dos genes Cas representa um tipo de proteína que ajuda no estabelecimento de uma memória molecular nas células bacterianas, na forma de uma integração de sequência genômica (viral) nas regiões presentes na matriz CRISPR (KOLLI et al., 2017). A proteína Cas9 é derivada da cepa de bactéria Streptococcus pyogenes (SpCas9) ou Staphylococcus aureus (SaCas9) que, teoricamente, conseguem clivagem de DNA em qualquer locus genômico de interesse (WU et al., 2017).

\section{Como as bactérias fazem uso desse recurso}

Os vírus infectam as bactérias e se propagam integrando a informação genética no DNA bacteriano. CRISPR/Cas9 é um tipo de mecanismo imune adaptativo presente na maioria das bactérias e as ajudam a proteger da invasão viral. O sistema CRISPR/Cas9 é capaz de incorporar sequências derivadas de DNA/RNA em um lócus já encontrado pela Cas9. Sobre transcrição e tradução deste lócus CRISPR, é formada juntamente com as proteínas Cas um complexo, então a Cas9 liga ao RNA que guia para a sequência de DNA viral alvo. Sobre reinfecção, as bactérias utilizam a sequência viral armazenada, a fim de destruir o ácido nucleico patógeno invasor (KOLLI et al., 2017).

Ao longo dos últimos anos, o CRISPR foi capturando a atenção da comunidade científica de várias maneiras, abrangendo seu papel na condução da interação co-evolutiva entre bactérias e seus vírus, e o desenvolvimento das tecnologias baseadas nesse sistema (BIKARD; BARRANGOU, 2017). 


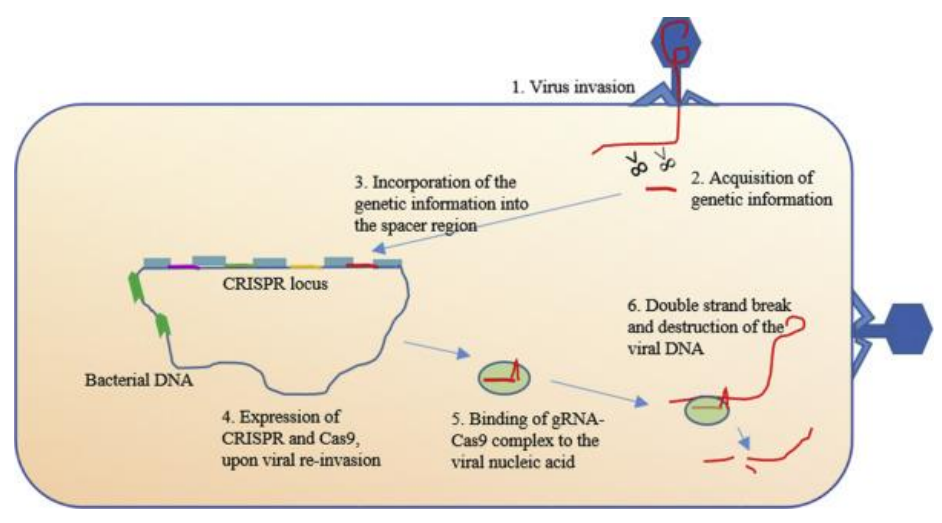

Figura 1- Etapas envolvidas na imunidade mediada por CRISPR em procariotas. 1 - Invasão do vírus; 2-Aquisição da informação genética; 3 - Incorporação da informação genética nas regiões espaçadas existentes, denominadas lócus, onde ocorre o armazenamento dessa informação; 4 - Em uma segunda invasão, é então que acontece a expressão do CRISPR/Cas9; 5 - Forma-se moléculas curtas de RNA guia (gRNAs) - Cas complexos enzimáticos O complexo gRNA-Cas combina com a sequência alvo no vírus invasor e o separa; 6 - O DNA viral é cortado, tornando-se instável e destruído. (KOLLI et al., 2017)

\section{O funcionamento da técnica}

Através dos estudos e de todo conhecimento adquirido do sistema, foi possível entender como é o mecanismo imune que as bactérias utilizam para se protegerem de um DNA estranho. E sendo assim, atualmente é possível utilizar como um mecanismo de edição genética. Todas as plataformas de edição do genoma, tais como: ZFNs (Zinc-Finger Nucleases), TALENs (Transcription Activator-Like Effector Nucleases) e CRISPR/Cas, operam fazendo rupturas direcionadas no DNA cromossômico, que utiliza DSB (Double-Strand Breaks). Como mostra a figura 2.

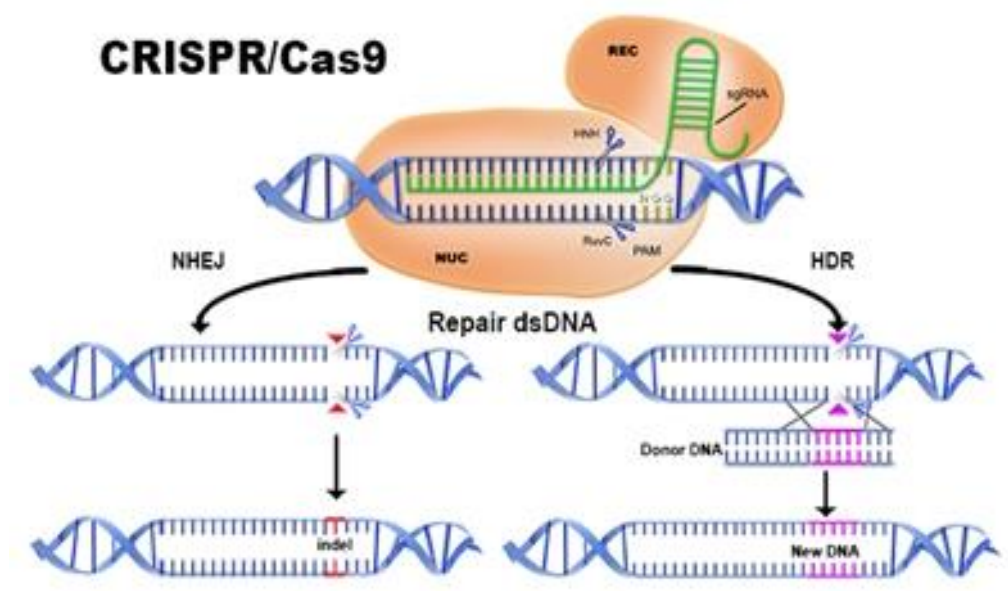

Figura 2 - Processos de reparo do DNA. Os processos de reparo celular converte as rupturas nas mutações locais de inserção e deleção por junção final não-homogênea (NHEJ) ou incorporam sequencias de um DNA doador para modificar o locus alvo por reparo homologicamente independente (HDR).

Fonte: <http://www.sinobiological.com/crispr-cas9-genome-editing.html>. Acesso em: 07 out. 2017.

As nucleases de edição do genoma devem ser introduzidas eficientemente nas células e, finalmente, no núcleo. No caso do CRISPR, envolve a introdução de um efetor Cas, como por exemplo, Cas9 (DEWITT et al, 2017), que usa um RNA guia (gRNA) para reconhecer e clivar alvos de DNA 
cognatos de uma maneira específica de sequência, onde o gRNA contém a sequência complementar do alvo (MITSUNOBU et al., 2017).

O CRISPR/Cas9 do tipo II foi descoberto através de estudos com bactérias Streptococcus pyogenes, e foi adaptado para edição genética. Se trata de uma quebra direcionada da endonuclease Cas9 complexado com um RNA guia, são reparados pela junção não homóloga, causando assim uma mutação, como uma deleção, por exemplo, e um gene que interrompe sua função. Na presença de um doador de homologia, as pausas induzidas por Cas9 podem ser reparadas por uma recombinação homóloga, resultando em integração específica do sítio. Coletivamente, as ferramentas de edição e regulação do genoma CRISPR/Cas9 permitem a capacidade de controlar a edição genética da forma desejada (SCHWARTZ et al., 2017).

As outras técnicas de edição genética, ZFNs e TALEN, reconhecem sequências de DNA específicas através de interações proteína-DNA, enquanto que a especificidade do DNA das proteínas Cas, o RNA é guiado. Comparado com ZFNs e TALENs, o CRISPR/Cas9 permite uma maior especificidade através do uso de RNAs de guia único (sgRNAs), com a vantagem de que a sequência pode seja projetado facilmente e gerado rapidamente. Outra vantagem principal do sistema CRISPR/Cas9 sobre ZFNs e TALENs é que múltiplos podem ser editados simultaneamente com o uso de diferentes sgRNAs. Essas características tornam CRISPR/Cas9 muito útil para estudar interações genéticas de múltiplos genes de controle (WU et al., 2017). Na figura 3, são mostrados os diferentes mecanismos de edição genética citadas.

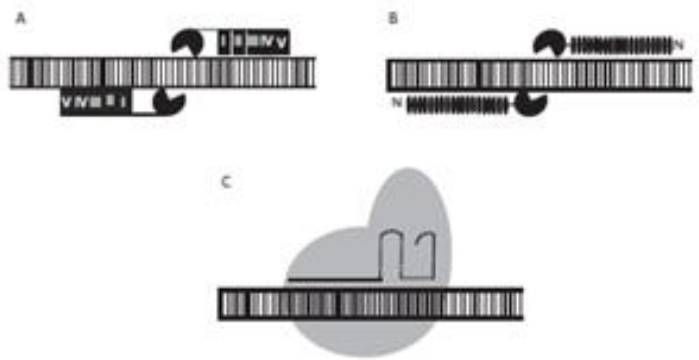

Figura 3 - As diferentes classes de editores do genoma. A - ZFN e B - TALEN: usam proteínas para detectar e ligar a sequência do DNA alvo, o que torna a síntese das nucleases de DNA uma abordagem mais difícil, em comparação com a C - CRISPR/Cas9 que usa RNA, sequências curtas para se ligar a sequência de DNA direcionada, tornando este sistema mais economicamente acessível e fácil de utilizar. (PETERSEN, 2017).

Desde a primeira descrição do uso bem-sucedido do CRISPR/Cas para segmentação de um locus genômico específico, o número de relatórios com experimentos tem aumentado e a grande parte dos centros de pesquisa passaram a utilizar o novo sistema CRISPR /Cas9 como editor de genoma para o propósito que eles buscam. (PETERSEN, 2017). 


\section{O uso da técnica relacionada ao tratamento do vírus da imunodeficiência humana (HIV)}

Até à data, a infecção pelo HIV continua a ser uma das pandemias mais evasivas que o mundo já viu. Dados da OMS indicam que mais de 37 milhões de pessoas vivem com HIV em todo o mundo e HIV foi responsável por mais de 1 milhão de óbitos em 2015, dos quais a maioria é causada por insuficiência de acesso a combinação de fármacos para manter a infecção por HIV sob controle, predominantemente no mundo em desenvolvimento. Essa combinação suprime eficientemente a replicação viral, mas não é capaz de eliminar o vírus completamente, tornando o HIV uma doença gerenciável e incurável. O HIV se integra de forma estável dentro do genoma das células infectadas e permanece quiescente como um reservatório latente que é, no entanto, totalmente capaz de reabastecer a replicação viral quando o tratamento é interrompido. Portanto os pacientes exigem criticamente um tratamento vitalício para assegurar um controle viral sustentado e eficiente. Melhorias na eficácia do tratamento diminuiu drasticamente a probabilidade de doenças que definem a AIDS, prolongando substancialmente a expectativa de vida das populações infectadas pelo HIV. No entanto, o fardo diário dos fármacos, suas toxicidades associadas e seus recursos limitados, tornam a vida útil e acessível a todos os tratamentos extremamente desafiador (HUYGHE et al., 2017)

A terapia genética está sendo considerada também uma solução para doenças infecciosas graves, liderado por um foco no vírus da imunodeficiência humana (HIV). Embora a terapia antiretroviral (ART) possa controlar a infecção pelo HIV na maioria dos pacientes, atualmente não há vacina ou cura para o vírus devido a sua alta taxa mutagênica, subversão do sistema imunológico do hospedeiro e capacidade de permanecer latente por longos períodos de tempo em células $T$ de longa duração. A única exceção a esta realidade é o chamado paciente de Berlim, que parece ter sido curado devido a um transplante de medula óssea de um doador com duas cópias de um gene CCR5 defeituoso, CCR5D32. Embora CRISPR/Cas9 seja semelhante em ação e eficácia para nucleases direcionadas baseadas em proteínas, como nucleases de zinco (ZFNs) e as nucleases efetoras do tipo ativador da transcrição (TALENs), a facilidade de concepção e teste destes reagentes através da construção de um único guia RNAs (sgRNAs) disponibilizou a edição de genes para uma maior variedade de usuários e aplicações. As nucleases direcionadas podem cortar ou vincular o DNA de uma maneira específica de sequencia, e tornaram possíveis várias novas aplicações que não eram anteriormente viáveis em seres humanos. Essas técnicas, juntamente com abordagens de terapia genéticas mais clássicas, utilizam vetores para expressar genes ou reguladores de RNA, fornecem uma variedade de abordagens para o tratamento do HIV e outras doenças infecciosas. No contexto da infecção pelo HIV, as tecnologias de interrupção de genes oferecem o potencial para replicar o caso do paciente de Berlim. As nucleases direcionadas também podem ser projetadas para reconhecer diretamente o material genético viral, para a codificação de regiões no genoma viral, para inativar genes virais essenciais, ou para o flanqueamento longo repetições terminais (LTRs) que controlam transcrição e replicação viral. A inativação do HIV pode então ocorrer como resultado da formação de deleções que perturba a região alvo, ou alternativamente porque as nucleases direcionadas às LTRs podem consumir a maior parte 
do HIV genoma criando DSBs em ambos os extremos do genoma proviral. Embora a formação de deleções resultante da ação de nucleases direcionadas possa levar a inativação proviral do HIV, evidências sugerem que o HIV também pode mutar e escapar de tais nucleases específicas de seqüência. A resistência pode ocorrer por causa da taxa de mutagênese naturalmente alta, ou porque os indels gerados durante o reparo do NHEJ podem destruir a sequência de reconhecimento de nuclease. É provável que este seja um grande mecanismo de fuga viral, particularmente se a sequência editada pode ser tolerada.Como o HIV, a infecção crônica pelo vírus da hepatite B (VHB) pode atualmente ser controlada por drogas que inibem a replicação viral. No entanto, estes não eliminam o covalente fechado genoma de DNA circular (cccDNA), que podem permanecer dentro de hepatócitos infectados. (ROGERS; CANNON, 2017).

Numerosos investigadores demonstraram a capacidade de CRISPR/Cas9, ZFNs ou TALENs para limpar cccDNA de VHB de células infectadas in vitro, bem como modelos in vivo com base no código de DNA de VHB e CRISPR/Cas9 a hepatócitos via hidrodinâmica injeção de plasmídeos. Outros vírus nos quais os genomas de DNA foram alvo da CRISPR/Cas9 incluem vírus do papiloma humano, vírus Epstein-Barr, herpes vírus simplex e vírus John Cunningham. Deve-se notarque estes são todos latentes ou infecções persistentes, continuando o tema de alinhar material genético que o sistema imunológico não pode erradicar. Também é possível clivar os genomas de RNA. O Streptococcus prototípico pyogenes Cas9 requer uma sequência de motivos adjacentes protospacer (PAM). No entanto, ao fornecer o PAM no trans como um oligonucleótido de DNA, é possível também direcionar as moléculas de RNA, que está abrindo estas abordagens para outras famílias de vírus. Em alternativa, outros membros do CRISPR/Cas9 foram identificados por possuir capacidade de direcionamento de RNA e pode atingir o vírus da hepatite $\mathrm{C}$ (genoma de 1RNA) em células eucarióticas. (ROGERS; CANNON, 2017).

As terapias genéticas destinadas a melhorar a função imunológica são outra área intrigante sendo considerado para o tratamento de doenças infecciosas. Uma estratégia particularmente interessante envolve redirecionar as células T CD81 para direcionar as células infectadas pelo HIV através de modificações ex vivo que levam à expressão de receptores de células $T$ específicos de patógenos (ROGERS; CANNON, 2017)

\section{Conclusão}

O desenvolvimento da presente pesquisa da literatura publicada possibilitou uma análise do que é a edição genética, o que se pode obter através dela e como essa ação pode trazer melhorias para as pessoas, por meio de uma tecnologia cada vez mais avançada; oferecendo, no futuro grandes mudanças. Além disso, também permitiu o conhecimento de ferramentas de edição podendo entender o funcionamento e diferenças entre as mesmas. Destacando o sistema CRISPR/Cas9, que está sendo bastante estudado pelos pesquisadores e sendo testada para diversos tipos de tratamentos de algumas 
doenças. Essa técnica foi descoberta através de estudos com bactérias, onde foi possível perceber que é um meio de defesa utilizado pelas bactérias contra DNA invasor. Então, o sistema age da seguinte maneira: a Cas9 é uma enzima que corta DNA, e a CRISPR é uma coleção de sequências de DNA que dizem à Cas9 onde exatamente deve cortar, que juntamente com o RNA guia formam um complexo e vão até o sítio exato para realizar a edição. Dada à importância do assunto, torna-se possível acreditar que será possível futuramente grande avanço científico, e podendo existir até mesmo o tratamento para doenças que atualmente não existe cura.

O número de experimentos utilizando a técnica está avançando cada dia mais, a fim de que se possa concretizar a técnica e encontrar soluções para situações que atualmente não existe.

\section{Referências}

AREND, M. C.; PEREIRA, J. O.; MARKOSKI, M. M. O Sistema CRISPR/Cas9 e a Possibilidade de Edição Genômica para a Cardiologia. Arquivos Brasileiros de Cardiologia, São Paulo, v. 108, n. 1, p. 81-83, jan. 2017.

BIKARD, D.; BARRANGOU, R. Using CRISPR-Cas systems as antimicrobials. Current opinion in Microbiology. v. 37, p.155-160, jun. 2017.

DEWITT, M.; CORN, J.; CARROLL, D. Genome editing via delivery of Cas9 ribonucleoprotein. Methods, San Diego, California, v.121-122, p. 9-15, maio 2017.

GAO, W. et al. Genome Editing in Cotton with the CRISPR/Cas9 System. Frontiers in Plant Science, ago. 2017.

HUIJBERS, I. J. Generating Genetically Modified Mice: A Decision Guide. Site-Specific Recombinases. Methods in Molecular Biology. Nova lorque, v. 1642, p. 1-19, ago. 2017.

HUYGHE, J.; MAGDALENA, S.; VANDEKERCKHOVE, L. Fight fire with fire: Gene therapy strategies to cure HIV. Expert Review of Anti-infective Therapy, v. 15, n. 8, p. 747-758, jul. 2017.

KOLLI, N. et al. Application of the gene editing tool, CRISPR-Cas9, for treating neurodegenerative diseases. Neurochemistry International, v. 112, p. 187-196, jul. 2017.

LIN, J. et al. Progress and Application of CRISPR/Cas Technology in Biological and Biomedical Investigation. Journal of Cellular Biochemistry. Guangdong, v.118, p.3061-3071, jun. 2017.

MEN, K. et al. CRISPR/Cas9-mediated correction of human genetic disease. Science China Life Sciences. v. 60, cap. 5, p. 447-457, maio 2017.

MITSUNOBU, H. et al. Beyond Native Cas9: Manipulating Genomic Information and Function. Trends in Biotechnology. v. 35, cap. 10, p.983 - 996, jul. 2017.

MUSURUNU, K. The Hope and Hype of CRISPR-Cas9 Genome Editing. JAMA Cardiology. v. 2, cap. 8, p. 914, ago. 2017.

NICHOLSON, S. A.; PEPPER, M. S. CRISPR-Cas: Revolutionising genome engineering. South African Medical Journal. v. 106, cap. 9, p. 870, ago. 2016.

PETERSEN, B. Basics of genome editing technology and its application in livestock species. Reproduction in Domestic Animals, v. 52, p. 4-13, ago. 2017. 
ROGERS, G. L.; CANNON, P. M. Gene Therapy Approaches to Human Immunodeficiency Virus and Other Infectious Diseases. Hematology/Oncology Clinics of North America. v. 31, cap. 5, p. 883895, set. 2017.

SCHWARTZ, C. et al. CRISPRi repression of nonhomologous end-joining for enhanced genome engineering via homologous recombination. Biotechnology and Bioengineering, v. 114, n.12, dez. 2017.

WU, W. et al. Application of CRISPR-Cas9 in eye disease. Experimental Eye Research, v. 161, p. 116123, ago. 2017.

ZHENG, Y. et al. Development of a versatile and conventional technique for gene disruption in filamentous fungi based on CRISPR-Cas9 technology. Scientific Reports, v. 7, n. 1, ago. 2017. 